\title{
AEROBIC CAPACITY OF CHILEAN ADULTS AND ELDERLY: PROPOSAL OF CLASSIFICATION BY REGIONAL PERCENTILES
}

\author{
CAPACIDADE AERÓBIA DE ADULTOS EIDOSOS CHILENOS: PROPOSTA DE CLASSIFICAÇÃO POR \\ PERCENTIS REGIONAIS
}

Original Article

ARTIGO ORIGINAL

Artículo Original

\author{
CAPACIDAD AERÓBICA DEADULTOS Y ANCIANOS CHILENOS: PROPUESTA DECLASIFICACIÓN POR \\ PERCENTILES REGIONALES
}

\author{
Luis Alberto Urzua Alul ${ }^{1}$ \\ (Physiotherapist and Physical \\ Education Professional) \\ Rossana Gomez-Campos ${ }^{2}$ \\ (Physical Education Professional) \\ Alejandro Almonacid-Fierro² \\ (Physical Education Professional) \\ Lisbetty Morales-Mora² \\ (Physiotherapist) \\ Edgardo Rojas-Mancilla ${ }^{3}$ \\ (Medical Technologist) \\ Iván Palomo ${ }^{4}$ \\ (Medical Technologist) \\ Jorge Méndez-Cornejo ${ }^{5}$ \\ (Physical Education Professional) \\ Daniel Leite Portella ${ }^{6}$ \\ (Physical Education Professional) \\ Marco Cossio-Bolaños ${ }^{5}$ \\ (Physical Education Professional)
}

1. Escuela de Kinesiología, Facultad de Salud, Universidad Santo Tomas, Chile. 2. Universidad Autónoma de Chile, Talca, Chile.

3. Universidad Bernardo O Higgins, Department of Chemical and Biological Sciences, General Gana

1780, Santiago, Chile.

4. Universidad de Talca, Facultad de Ciencias de la Salud, Department of Clinical Biochemistry and 5 . Immunohematology, Talca, Chile. Universidad Católica del Maule, Talca, Chile.

6. Universidade Municipal de São Caetano do Sul, Faculdade de Educação Física, Escola da Saúde, Research and Study Group - Sport and Exercise Sciences, São Caetano do Sul, SP, Brazil.

\section{Correspondence:}

Rossana Gómez Campos Universidad Autónoma de Chile. 5 Poniente 1670, Talca, Chile. rossaunicamp@gmail.com

\begin{abstract}
Introduction: Aerobic fitness is an important predictor that contributes to the preservation of functional independence during the aging process. Its measurement represents a fundamental tool in the identification of multiple health problems. Objective: To compare the aerobic capacity of adults and elderly subjects through international studies and to develop percentiles by age group using the LMS method. Methods: A cross-sectional descriptive study was conducted with 1146 subjects (437 men and 709 women). The age group of the sample ranged from 50 to 84 years. The subjects evaluated came from the physical activity programs offered by the National Sports Institute (IND) and by the city council of Talca (Chile). Body mass, stature, oxygen saturation (SatO2), six-minute walk test, and systolic and diastolic blood pressure were assessed. Body Mass Index (BMI) was calculated for both sexes. The LMS method was used to propose the percent distribution. Results: Aerobic capacity decreases with age (28.5\% for men and $29.9 \%$ for women). There was a negative relationship between age and the six-minute walk test (men $r=-0.13$ and women $r=-0.39$ ). There was a discrepancy between the elderly subjects in the current study and those from international studies. The normative data for the classification of aerobic fitness were expressed in percentiles (p3, p5, p10, p15, p25, p50, p75, p85, p90, p95 and p97). Conclusion: The aerobic performance of elderly subjects diminishes as they age; in addition, the current results differ from international studies, which motivated the development of percentiles to classify aerobic fitness in everyday situations, especially in places with few resources and particularly where field tests are considered a priority for large-scale physical evaluation. Level of evidence Il; Diagnostic studies - investigation of diagnostic test.
\end{abstract}

Keywords: Exercise; Aged; Walk test; Exercise test.

\section{RESUMO}

Introdução: A aptidão aeróbia é importante preditor que contribui com a preservação da independência funcional à medida que se envelhece. Sua mensuração transforma-se em ferramenta fundamental na identificação de múltiplos problemas de saúde. Objetivo: Comparar a capacidade aeróbia de adultos e idosos com estudos internacionais e desenvolver percentis por faixas etárias, utilizando o método LMS. Métodos: Elaborou-se um estudo descritivo transversal com 1.146 sujeitos (437 homens e 709 mulheres). A faixa etária da amostra variou de 50 a 84 anos. Os sujeitos avaliados eram oriundos dos programas de atividade física oferecidos pelo Instituto Nacional de Desporto (IND) e pela prefeitura de Talca (Chile). Avaliaram-se massa corporal, estatura, saturação de oxigênio $\left(\mathrm{SatO}_{2}\right)$, teste de caminhada de 6 minutos e pressão arterial diastólica e sistólica. Calculou-se o índice de massa corporal (IMC) para ambos os sexos. Utilizou-seo método LMS para propor a distribuição percentílica. Resultados: A capacidade aeróbia diminui com o decorrer da idade (28,5\% para os homens e $29,9 \%$ para as mulheres). Houve relação negativa entre a idade e o teste de caminhada de 6 minutos (homens: $r=-0,13$; mulheres: $r=-0,39$ ). Observou-se discrepância entre os idosos do presente estudo com os de estudos internacionais. Os dados normativos para a classificação da aptidão aeróbia foram expressos em percentis (p3, p5, p10, p15, p25, p50, p75, p85, p90, p95 y p97). Conclusão: Os idosos diminuem o desempenho aeróbio conforme a idade avança. Os presentes resultados diferem dos estudos internacionais, o que motivou o desenvolvimento dos percentis para classificar a aptidão aeróbia em situações cotidianas, especialmente em locais com poucos recursos e principalmente onde os testes de campo são considerados prioritários para avaliação física em larga escala. Nível de evidência ll; Estudos diagnóstico - investigação de teste diagnóstico.

Descritores: Exercício; Idoso; Teste de caminhada; Teste de esforço.

\section{RESUMEN}

Introducción:La aptitud aeróbica es un importante predictor que contribuye con la preservación de la independencia funcional a medida que se envejece. Su medición se transforma en una herramienta fundamental en la identificación de múltiples problemas de salud. Objetivo: Comparar la capacidad aeróbica de adultos y ancianos con estudios internacionales y desarrollar percentiles por grupos de edad utilizando el método LMS. Métodos: Se elaboró un estudio descriptivo transversal con 1146 sujetos (437 hombres y 709 mujeres). El grupo de edad de la muestra varió de 50 a 84 años. Los sujetos evaluados eran oriundos de los programas de actividad física ofrecidos por el Instituto Nacional de Deporte (IND) y por la Municipalidad de Talca (Chile). Seevaluaron masa corporal, estatura, saturación de oxígeno $\left(\mathrm{SatO}_{2}\right)$, test de seis minutos 
de caminatay presión arterial diastólica y sistólica. Se calculó el índice de masa corporal (IMC) para ambos sexos. Se usóel método LMS para proponer la distribución de percentil. Resultados: La capacidad aeróbica disminuye con el transcurso de la edad (28,5\% para los hombres y 29,9\% para las mujeres). Hubo relación negativa entrela edad yel test de caminata de seis minutos (hombres $r=-0,13$ y mujeres $r=-0,39$ ). Seobservó discrepancia entre los ancianos del presenteestudio con los de estudios internacionales. Los datos normativos para la clasificación de la aptitud aeróbica fueron expresados en percentiles (p3, p5, p10, p15, p25, p50, p75, p85, p90, p95 y p97). Conclusión: Los ancianos disminuyen el rendimiento aeróbico conforme avanza la edad. Los presentes resultados difieren de los estudios internacionales, lo que motivó el desarrollo de los percentiles para clasificar la aptitud aeróbica en situaciones cotidianas, especialmente en locales con pocos recursos y principalmente donde los tests de campo son considerados prioritarios para la evaluación física a larga escala. Nivel de Evidencia Il;

\section{Estudios diagnóstico-investigación de test diagnóstico.}

Descriptores: Ejercicio; Anciano; Prueba de paso; Prueba de esfuerzo.

\section{INTRODUCTION}

Functional aerobic capacity represents the maximum rate of oxygen consumption due to muscle contractions and is considered the gold standard measurement for the functional limit of the cardiorespiratory system. ${ }^{1}$ It is one of the main variables in the field of exercise physiology and is frequently used to indicate aerobic fitness.

In general, it is measured objectively by means of a laboratory and/ or field stress test. It is useful to assess the physical condition of an individual, to diagnose and/or predict ischemic heart disease, to develop an exercise prescription, and to guide cardiac rehabilitation processes. ${ }^{2}$

Aerobic capacity tends to decline with advancing age. ${ }^{3,4}$ These changes are associated with a progressive loss of functional independence in the elderly, as well as with the onset of risk and premature death. ${ }^{6}$

Thus, the classification of aerobic capacity in this population becomes relevant, as influencing the performance of daily activities regardless of the ability to maintain aerobic capacity and muscle strength. ${ }^{4}$

Therefore, several studies have used the six-minute walk test, which measures the functional and cardiorespiratory capacity of the elderly, to evaluate aerobic fitness. . $^{6-10}$ This test is used to classify the aerobic fitness of the elderly, in view of its good acceptance, its tolerance, and its ability to closely reflect daily activities. ${ }^{6}$

Functional fitness standards for the elderly, specifically regarding aerobic capacity, are currently being proposed in many regions of the world.9,11,12 These studies have normative values, which are used to evaluate performance standards in relation to age and sex, and according to each country. In countries such as Chile, which is in the process of implementing nutritional transition and presents substantial differences in sociocultural and regional issues, international standards could barely help identify the loss of functional mobility and physical independence in the elderly.

In this context, the proposal of a regional standard could be an alternative to identify the real state of aerobic fitness in the elderly. In addition, to the best of our knowledge, Chile does not have standards that allow diagnosing, classifying, and monitoring aerobic capacity of the elderly. Thus, it is necessary to introduce this information in elderly programs as a preventive health tool.

Therefore, the present study aims to a) compare the aerobic capacity of adults and elderly to international studies and b) develop percentiles by age and sex using the LMS method.

\section{MATERIALS AND METHODS}

A cross-sectional and descriptive study included 1,146 subjects (437 men and 709 women). Their age varied from 50 to 84 years old. The sample selection was non-probabilistic (accidental). The evaluated subjects signed an informed consent form (ICF) and were included in physical activity programs offered by the National Sports Institute (IND) and the Talca City Hall (Chile). The assessed volunteers were referred to the Maule Health Service in the city of Talca (Chile). This institution is part of the Risk Factors Research Program for Cardiovascular Disease (PIFRECV) of the University of Talca, Chile. The volunteers participated in a physical activity program, which was held once a week and lasted 90 minutes.

The participants were informed about the variables that would be collected during the research and the subjects that accepted these conditions were included in the study. Individuals presenting morbid obesity and/or a previous history of serious illnesses that prevented them from performing the six-minute walk test, such as heart failure, were excluded. This research was approved by the Ethics Committee of the Autonomous University of Chile, in Talca, under protocol number UA104-17, and was developed according to the Helsinki recommendations.

\section{Procedures}

Anthropometric and physiological evaluations were assessed in the movement analysis laboratory of the Kinesiology School of the University of Talca, Chile. All volunteers were assessed Monday through Friday between 8:30 and 11:00 am, from January to April 2015. The anthropometric evaluation was performed by an experienced professional who was trained to collect the samples. The physiological evaluation and the six-minute walk test were performed by two evaluators. Initially, anthropometric variables were measured, followed by physiological parameters. Subsequently, the six-minute walk test was performed.

Body mass $(\mathrm{kg})$ was recorded using an electronic scale (United Kingdom, Ltd) with $100 \mathrm{~g}$ accuracy. An aluminum stadiometer (Seca Gmbh \& Co. KG, Hamburg, Germany) was used to measure height. The body Mass Index (BMI) was calculated by the following formula $\left[\mathrm{BMI}=\right.$ Body Mass $(\mathrm{kg}) /$ Height $\left.(\mathrm{m})^{2}\right]$. Oxygen saturation level $\left(\mathrm{O}_{2} \mathrm{~S}\right)$ was measured by resting pulse oximetry ( $\mathrm{mmHg}$ ). A Nonin 8500 handheld pulse machine (Nonin Medical, Plymouth, MN), transmitting the signal with a red and infrared light, was used. Blood pressure was measured using a mercury sphygmomanometer with stethoscope (Riester) and the recommendations described by the Pan American Health Organization were followed ${ }^{13}$. The procedure consisted of a 10-minute period of rest, and then both the systolic blood pressure (SBP) and diastolic blood pressure (DBP) were recorded.

Before conducting the physical tests, the individual warmed-up for 10 to 15 minutes by performing flexibility, coordination, balance, and rhythm shifting exercises. The walk test was performed according to the suggestions of the American Thoracic Society ${ }^{6}$, in a closed gym, on a flat surface that was 30 meters long and 10 meters wide. Colored adhesive strips were placed every three meters. Cones were located to mark the 
end points of this 30-meter surface, as to identify the beginning and the end. The procedure consisted of evaluating the volunteers one by one. At the end of the six minutes, the participants' walking distance was recorded. The participants performed the test while wearing sportswear, warm clothing, and socks.

\section{Statistical analysis}

The data normality was verified using the Kolmogorov-Smirnov test. For the descriptive analysis, mean values and standard deviations were reported for each age group. Significant differences in sex were verified by the Student's t-test for independent samples. In this study, age groups were compared by sex, applying the one-way analysis of variance and Tukey's post hoc test. To compare the percentage of decline in aerobic capacity, the study published by Gusi et al ${ }^{12}$ in Spain, Marques et al ${ }^{9}$ in Portugal, and Rikli and Jones ${ }^{11}$ in the United States, were used. Pearson's $r$ was used to correlate the chronological age to the distance walked in the six-minute walk test. In all cases, a p-value of $<0.05$ was adopted. To generate smoothed percentiles for the six-minute walk test, by age and gender, we applied the LMS method ${ }^{14}$ using software (LMS Chart Maker version 2.3. $)^{15}$. The final percentile curves were smoothed to create three age-specific curves: $\mathrm{L}$ (Lambda; asymmetry), M (Mu; median) and $S$ (Sigma, coefficient of variation). The percentiles p3, p5, p10, p15, p25, p50, p75, p85, p90, p95, and p97 were calculated.

\section{RESULTS}

Table 1 shows the anthropometric and physiological variables that characterize this sample. Men presented a higher body mass and were taller compared to women $(\mathrm{p}<0.05)$. Regarding $\mathrm{BMI}$ and $\mathrm{O}_{2} \mathrm{~S}$, the values were similar in both sexes, except in the group aged between 55 and 59 years, in which women presented a higher $\mathrm{BMI}$ and $\mathrm{SO}_{2}$. Regarding the systolic blood pressure (SBP) women showed higher values in four age groups (50 to 69 years). In relation to diastolic blood pressure (DBP), men generally presented higher values, except in the group aged between 75 and 79 years.

Comparisons referring to the cardiorespiratory capacity obtained during the six-minute walk test are shown in Table 2. In general, men walked greater distances when compared to women ( $p<0.05)$, except the group aged between 55 and 59 years, where no significant differences were observed. When compared by age range, differences start to appear in men from 65-69 years onwards, while in women from 60-64 years onwards.

Figure 1 shows the negative relationship between chronological age and the results obtained during the six-minute walk test (men $r=$ -0.13 and women $r=-0.39$ ). As age increases, aerobic capacity decreases faster in women than in men. Table 2 also shows that the percentage decrease in aerobic capacity in both sexes was relatively higher when compared to that in studies published in Spain and the United States.

Table 1. Anthropometric and physiological characteristics of the studied sample.

\begin{tabular}{|c|c|c|c|c|c|c|c|c|c|c|c|c|c|}
\hline \multirow{2}{*}{$\begin{array}{c}\text { Age } \\
\text { range (years) }\end{array}$} & \multirow{2}{*}{$\mathrm{n}$} & \multicolumn{2}{|c|}{ Body mass $(\mathrm{kg})$} & \multicolumn{2}{|c|}{ Height $(\mathrm{cm})$} & \multicolumn{2}{|c|}{ BMI $\left(\mathrm{kg} / \mathrm{m}^{2}\right)$} & \multicolumn{2}{|c|}{$\mathrm{O}_{2} \mathrm{~S}(\mathrm{mmHg})$} & \multicolumn{2}{|c|}{$\mathrm{SBP}(\mathrm{mmHg})$} & \multicolumn{2}{|c|}{$\mathrm{DBP}(\mathrm{mmHg})$} \\
\hline & & $\mathrm{X}$ & SD & $\mathrm{X}$ & SD & $X$ & SD & $\mathrm{X}$ & SD & $\mathrm{X}$ & SD & $\mathrm{X}$ & SD \\
\hline & \multicolumn{13}{|c|}{ Men } \\
\hline 50 to 54 & 34 & 81.5 & 15.5 & 170.8 & 6.4 & 27.9 & 4.8 & 77.5 & 12.8 & 134.9 & 27.4 & 86.2 & 22.0 \\
\hline 55 to 59 & 32 & 74.3 & 8.6 & 168.3 & 7.5 & 26.2 & 2.2 & 78.0 & 17.0 & 131.1 & 14.8 & 82.3 & 15.0 \\
\hline 60 to 64 & 109 & 78.9 & 13.8 & 167.6 & 6.7 & 28.2 & 5.3 & 72.6 & 15.3 & 129.6 & 17.7 & 78.6 & 11.2 \\
\hline 65 to 69 & 87 & 74.5 & 11.6 & 166.5 & 8.0 & 26.8 & 3.5 & 75.6 & 13.6 & 130.9 & 21.4 & 79.3 & 11.0 \\
\hline 70 to 74 & 71 & 75.6 & 8.4 & 165.6 & 7.1 & 27.6 & 3.3 & 76.6 & 15.1 & 128.9 & 18.4 & 80.8 & 10.9 \\
\hline 75 to 79 & 68 & 74.3 & 11.9 & 164.9 & 7.1 & 27.3 & 4.3 & 77.4 & 10.0 & 130.1 & 18.4 & 77.7 & 11.4 \\
\hline 80 to 84 & 36 & 70.2 & 9.4 & 163.8 & 6.9 & 26.1 & 3.1 & 71.4 & 7.3 & 125.1 & 12.6 & 75.5 & 11.4 \\
\hline \multirow[t]{2}{*}{ Tottol } & 437 & 75.9 & 12.1 & 166.7 & 7.3 & 27.3 & 4.1 & 75.3 & 13.8 & 130.0 & 19.1 & 79.6 & 12.9 \\
\hline & \multicolumn{13}{|c|}{ Women } \\
\hline 50 to 54 & 56 & $72.0^{*}$ & 12.0 & $159.5^{*}$ & 5.6 & 28.3 & 4.2 & 79.0 & 13.3 & $123.3^{*}$ & 16.2 & $78.3^{*}$ & 14.1 \\
\hline 55 to 59 & 61 & $72.4^{*}$ & 12.4 & $155.3^{*}$ & 5.9 & $30.1^{*}$ & 5.4 & $82.1^{*}$ & 12.4 & $129.2^{*}$ & 20.4 & $77.1^{*}$ & 13.9 \\
\hline 60 to 64 & 214 & $70.6^{*}$ & 11.4 & $157.6^{*}$ & 6.4 & 28.5 & 4.6 & 77.2 & 13.7 & $127.5^{*}$ & 16.2 & $76.4^{*}$ & 11.3 \\
\hline 65 to 69 & 155 & $68.3^{*}$ & 11.4 & $156.9^{*}$ & 7.3 & 27.8 & 4.4 & 76.8 & 12.9 & $128.7^{*}$ & 17.6 & $76.7^{*}$ & 11.0 \\
\hline 70 to 74 & 123 & $68.0^{*}$ & 10.7 & $155.6^{*}$ & 6.2 & 28.1 & 4.1 & 76.6 & 13.6 & 129.1 & 17.7 & $76.0^{*}$ & 11.6 \\
\hline 75 to 79 & 57 & $66.3^{*}$ & 10.2 & $154.0^{*}$ & 6.5 & 28.0 & 4.1 & 76.9 & 15.3 & $134.8^{*}$ & 16.0 & 76.9 & 13.5 \\
\hline 80 to 84 & 43 & $64.3^{*}$ & 11.8 & $152.4^{*}$ & 7.1 & 27.7 & 4.9 & 76.7 & 12.0 & 128.5 & 17.8 & $73.7^{*}$ & 14.4 \\
\hline Total & 709 & 69.2 & 11.5 & 156.4 & 6.7 & 28.3 & 4.5 & $77.5^{*}$ & 13.4 & 128.5 & 17.4 & $76.5^{*}$ & 12.1 \\
\hline
\end{tabular}
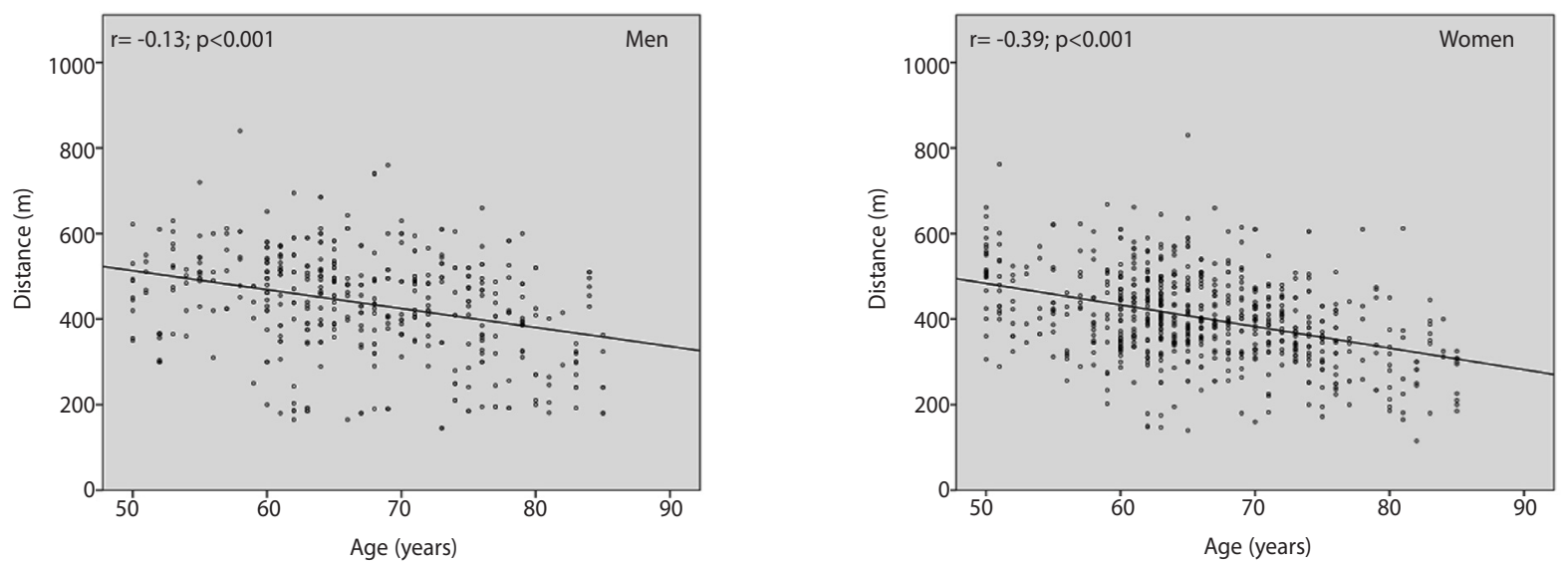

Figure 1. Relationship between chronological age and distance walked in the six-minute test by gender. 
However, these results were lower than those obtained in studies carried out in Portugal. In general, when compared to international studies, adults from Chile present a decreased aerobic capacity compared to those found in studies conducted in Portugal, Spain, and United States.

The percentile distribution of cardiorespiratory capacity, by age and sex, is shown in Table 3. In both genders, p3, p5, p10, p15, p25, p50, p75, p85, p90, p95, and p97 were calculated using the LMS method. In both cases, the values decrease as age increases.

\section{DISCUSSION}

The results in this study indicate that aerobic capacity decreases with advancing age in both sexes. These findings are consistent and comparable to findings in studies conducted in Japan, Portugal, United States, Spain and Brazil, 9,1012,16 which included subjects of a similar age range. Moreover, the negative correlations obtained with the elderly included in those studies reflect their decreased aerobic capacity. In general, aerobic fitness in the aging populations decreased by approximately $9-10 \%$ every 10 years; ${ }^{17}$ however, the decline values observed in this study and those monitored for over two decades were between $28.5 \%$ and $29.9 \%$.

These findings highlight a faster decrease in aerobic capacity when compared to studies carried out in Spain ${ }^{12}$ and the USA, ${ }_{1}^{11}$ for example. However, the elderly population in Portugal ${ }^{9}$ shows a faster decline (35.6\% to $37.6 \%$ in relation to the elderly population from Chile and other countries. These results suggest the need to prioritize physical activity as a strategy to improve the functional fitness and quality of life of the elderly, since physical exercise is inversely related to the development of heart disease, diabetes, certain cancers, depression, and most causes of mortality. ${ }^{18,19}$

Thus, maximum aerobic fitness is an important independent predictor of mortality in the elderly. ${ }^{20}$ Maintaining adequate levels of aerobic fitness can contribute to the preservation of functional independence while getting older. Therefore, its measurement is a fundamental tool to apply to adults and the elderly, since it can serve as an initial diagnosis to identify multiple health problems. ${ }^{21}$

Hence, from the differences observed in the six-minute walk test compared to international works, this study developed percentiles to classify aerobic capacity in middle-aged and elderly adults. The differences

Table 2. Means and standard deviations of the six-minute walk test (m).

\begin{tabular}{|c|c|c|c|c|c|c|c|c|c|}
\hline \multirow{2}{*}{ Age range (years) } & \multirow[b]{2}{*}{$\mathrm{n}$} & \multicolumn{2}{|c|}{ Chile-Study } & \multicolumn{2}{|c|}{ Spain } & \multicolumn{2}{|c|}{ USA } & \multicolumn{2}{|c|}{ Portugal } \\
\hline & & $\mathrm{X}$ & SD & $x$ & SD & $\mathrm{X}$ & SD & $x$ & SD \\
\hline & & \multicolumn{8}{|c|}{ Men } \\
\hline 50 to 54 & 34 & $512.7^{*}$ & 104.8 & -- & -- & -- & -- & -- & -- \\
\hline 55 to 59 & 32 & 462.7 & 95.4 & -- & -- & -- & -- & -- & - \\
\hline 60 to 64 & 109 & $456.1^{*}$ & 123.1 & 422.0 & 116.1 & 610.0 & 89.0 & -- & -- \\
\hline 65 to 69 & 87 & $437.2^{*}$ & $124.4^{a}$ & 430.4 & 84.0 & 597.0 & 92.0 & 544.2 & 140.4 \\
\hline 70 to 74 & 71 & $437.4^{*}$ & $110.9^{a}$ & 407.5 & 98.6 & 568.0 & 100.0 & 499.5 & 144.2 \\
\hline 75 to 79 & 68 & $399.7^{*}$ & $112.2^{\mathrm{ac}}$ & 386.0 & 100.8 & 500.0 & 142.0 & 433.3 & 162.3 \\
\hline 80 to 84 & 36 & $326.7^{*}$ & 110.9 abcdef & 345.2 & 102.2 & 505.0 & 99.0 & 350.2 & 139.0 \\
\hline \multirow[t]{2}{*}{$\%$ of decline } & -- & $28.5 \%$ & -- & $18.1 \%$ & -- & $17.2 \%$ & -- & $35.6 \%$ & -- \\
\hline & & \multicolumn{8}{|c|}{ Women } \\
\hline 50 to 54 & 61 & 421 & 102.5 & -- & -- & -- & -- & -- & -- \\
\hline 55 to 59 & 56 & 477.9 & 95.9 & -- & -- & -- & -- & -- & -- \\
\hline 60 to 64 & 214 & 421.8 & $93.0 \mathrm{~b}$ & 424.3 & 87.3 & 578.0 & 81.0 & -- & -- \\
\hline 65 to 69 & 155 & 414.1 & $96.5 b$ & 414.4 & 89.5 & 550.0 & 102.0 & 486.7 & 114.7 \\
\hline 70 to 74 & 123 & 384.1 & $80.4 b c$ & 385.7 & 84.3 & 539.0 & 87.0 & 453.9 & 119.8 \\
\hline 75 to 79 & 57 & 338.5 & $86.7^{\text {abcde }}$ & 359.9 & 89.0 & 503.0 & 100.0 & 378.4 & 140.6 \\
\hline 80 to 84 & 43 & 295.3 & 92.6 abcde & 318.7 & 92.8 & 484.0 & 83.0 & 303.7 & 137.1 \\
\hline$\%$ of decline & -- & $29.9 \%$ & -- & $25.0 \%$ & -- & $16.3 \%$ & -- & $37.6 \%$ & -- \\
\hline
\end{tabular}

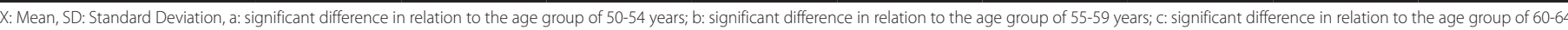

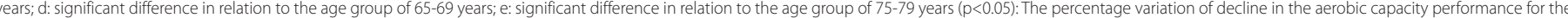
different age groups was calculated by dividing the variation of the age range: 60-64 years (Chile, Spain and United States) and 65-69 years (Portugal).

Table 3. Percentile distribution of the six-minute walk test $(\mathrm{m})$ by age range and sex. Percentile distribution of the six-minute walk test (m) by age range and gender.

\begin{tabular}{|c|c|c|c|c|c|c|c|c|c|c|c|c|c|c|}
\hline Age range (years) & $L$ & $M$ & $S$ & P3 & P5 & P10 & P15 & P25 & P50 & P75 & P85 & $\mathrm{P} 90$ & P95 & P97 \\
\hline & \multicolumn{14}{|c|}{ Men $(n=437)$} \\
\hline $50-54$ & 1.37 & 491.43 & 0.22 & 266.2 & 297.6 & 343.8 & 373.6 & 416.2 & 491.4 & 562.6 & 599.4 & 623.9 & 659.5 & 682.2 \\
\hline $55-59$ & 1.14 & 472.31 & 0.20 & 286.5 & 310.6 & 347.2 & 371.6 & 407.1 & 472.3 & 536.2 & 570.1 & 592.8 & 626.3 & 648.0 \\
\hline $60-64$ & 1.57 & 472.17 & 0.24 & 220.3 & 259.0 & 313.0 & 346.5 & 393.0 & 472.2 & 544.4 & 581.0 & 605.1 & 639.8 & 661.8 \\
\hline $65-69$ & 1.56 & 452.04 & 0.25 & 192.0 & 233.0 & 289.2 & 323.8 & 371.4 & 452.0 & 525.2 & 562.2 & 586.5 & 621.5 & 643.6 \\
\hline $70-74$ & 1.37 & 434.31 & 0.27 & 186.6 & 222.6 & 274.3 & 307.2 & 353.5 & 434.3 & 509.8 & 548.6 & 574.3 & 611.7 & 635.5 \\
\hline $75-79$ & 1.02 & 394.44 & 0.29 & 180.6 & 207.6 & 249.1 & 277.0 & 318.1 & 394.4 & 470.5 & 511.2 & 538.7 & 579.5 & 606.0 \\
\hline \multirow[t]{2}{*}{$80-84$} & 0.56 & 327.16 & 0.31 & 161.0 & 179.0 & 208.3 & 229.2 & 261.7 & 327.2 & 399.0 & 440.0 & 468.9 & 513.1 & 542.7 \\
\hline & \multicolumn{14}{|c|}{ Women $(n=709)$} \\
\hline $50-54$ & 0.89 & 469.04 & 0.21 & 287.0 & 309.3 & 343.9 & 367.5 & 402.6 & 469.0 & 536.6 & 573.2 & 598.2 & 635.4 & 659.7 \\
\hline $55-59$ & 0.98 & 434.48 & 0.22 & 257.2 & 279.3 & 313.5 & 336.6 & 370.7 & 434.5 & 498.4 & 532.8 & 556.1 & 590.7 & 613.2 \\
\hline $60-64$ & 0.98 & 421.32 & 0.22 & 246.5 & 268.3 & 301.9 & 324.7 & 358.4 & 421.3 & 484.5 & 518.5 & 541.5 & 575.7 & 598.0 \\
\hline $65-69$ & 0.81 & 410.23 & 0.23 & 243.2 & 263.2 & 294.6 & 316.2 & 348.5 & 410.2 & 473.8 & 508.6 & 532.4 & 568.1 & 591.5 \\
\hline $70-74$ & 0.64 & 378.78 & 0.24 & 225.1 & 242.8 & 270.9 & 290.5 & 320.4 & 378.8 & 440.6 & 475.1 & 499.0 & 535.3 & 559.3 \\
\hline $75-79$ & 0.48 & 334.53 & 0.25 & 194.4 & 209.9 & 234.8 & 252.5 & 279.8 & 334.5 & 394.4 & 428.6 & 452.6 & 489.4 & 514.1 \\
\hline $80-84$ & 0.34 & 287.90 & 0.28 & 161.8 & 175.1 & 196.8 & 212.5 & 237.1 & 287.9 & 345.4 & 379.1 & 403.2 & 440.7 & 466.2 \\
\hline
\end{tabular}


observed in the study demonstrate that the use of international percentile standards could overestimate and/or underestimate the results obtained in the studied individuals.

The percentiles proposed in this study for middle-aged and elderly adults of both sexes might contribute to further investigations, practical health implementation methods, and prevent the decline in aerobic fitness. Thus, normative standards should be generally used to disclose an individual's state in relation to the population and are fundamental to analyze future international trends and comparisons. ${ }^{9}$

Therefore, in a country like Chile, where $11.4 \%$ of the population is elderly, a percentage that keeps increasing significantly, 22 the percentiles we developed might provide valuable information to health science professionals. They can provide education, motivation, and can raise awareness in the older population regarding the organization and planning of intervention programs, according to the subjects' needs. In addition, the government can provide guidance to implement preventive health strategies and policies. ${ }^{21,23}$

As a consequence, the normative values proposed herein can be used to classify, diagnose, and monitor the aerobic capacity of middle-aged and elderly adults of both sexes. The cutoff points established for men and women can be interpreted as the following. A score lower than p15 indicates a low level and/or warning signal, p15 and p85 indicates an adequate status, and above p85 indicates a high level of aerobic fitness. This information can also help monitor the aerobic fitness performance by professionals working with this population and set proper goals.
In addition, it is not uncommon that clinical professionals and/or researchers use international references to diagnose and classify their patients. ${ }^{24}$ Therefore, the references proposed in this study are, crucial at both the Chilean regional and national levels.

Some limitations should be pointed out, such as the low percentage of men included in this study when compared to women and the lack of reliable criteria (test and retest) in the six-minute walk test. Such limitations could lead to slight bias in quantifying the results. Nevertheless, this is the first study that was performed in Chile. Moreover, its easy applicability, low cost, and high reproducibility enable the use of the six-minute walk test in several investigations regarding the elderly populations 9,12 , serving also as a potential reference for future studies.

\section{CONCLUSION}

In conclusion, the aerobic capacity of the elderly decreases with advancing age. However, the difference between the results obtained and the data collected in international studies encourages development of the percentiles capable of classifying daily aerobic fitness, especially in situations of scarce resources, and when field tests are considered a priority for a large-scale evaluation. Calculations can be performed using the following link: http://www.reidebihu.net/ testcaminata.php

All authors declare no potential conflict of interest related to this article

AUTHORS' CONTRIBUTIONS: Each author made significant individual contributions to this manuscript. LAUA (0000-0002-5792-2191)*: evaluations and data collection; RGC (0000-0001-6509-5707);: writing of the manuscript and evaluation of data from the statistical analysis; AAF (0000-0002-8328-017X)*: evaluations and data collection; LMM (00000002-8322-2682)*: evaluations and data collection; ERM (0000-0001-9684-3827)*: evaluations and data collection; IP (0000-0002-9618-8778)*: evaluations and data collection; JMC (0000-0002-3925-170X)*: writing of the manuscript; DLP (0000-0002-5259-9049)*: literature search, review of the manuscript, and contribution to the intellectual concept of the study; MCB (0000-0001-7230-9996)*: evaluation of data from the statistical analysis; literature search, review of the manuscript, and contribution to the intellectual concept of the study. All authors approved the final version of the manuscript. *ORCID (Open Researcher and Contributor ID).

\section{REFERENCES}

1. Saltin B, Strange S. Maximal oxygen uptake: "old" and "new" arguments for a cardiovascular limitation. Med Sci Sports Exerc. 1992;24(1):30-7.

2. Huggett DL, Connelly DM, Overend TJ. Maximal aerobic capacity testing of older adults: a critical review. J Gerontol A Biol Sci Med Sci. 2005;60(1):57-66.

3. Buskirk ER, Hodgson JL. Age and aerobic power: the rate of change in men and women. Federation Proc. 1987;46(5):1824-9.

4. Fleg JL, Morrell CH, Bos AG, Brant $L$, Talbot LA, Wright JG, et al. Accelerated longitudinal decline of aerobic capacity in healthy older adults. Circulation. 2005;112(5):674-82.

5. Wilson TM, Tanaka H. Meta-analysis of the age-associated decline in maximal aerobic capacity in men: relation to training status. Am J Physiol Heart Circ Physiol. 2000;278(3):H829-34

6. Fitzgerald MD, Tanaka H, Tran ZV, Seals DR. Age-related declines in maximal aerobic capacity in regularly exercising vs. sedentary women: a meta-analysis. J Appl Physiol (1985). 1997;83(1):160-5.

7. ATS Committee on Proficiency Standards for Clinical Pulmonary Function Laboratories. ATS Statement: Guidelines for the six-minute walk test. Am J Respir Crit Care Med. 2002;166(1):111-7.

8. Burr JF, Bredin SS, Faktor MD, Warburton DE. The 6-minute walk test as a predictor of objectively measured aerobic fitness in healthy working-aged adults. Phys Sports Med. 2011;39(2):133-9.

9. Marques EA, Baptista F, Santos R, Vale S, Santos DA, Silva AM, et al. Normative Functional Fitness Standards and Trends of Portuguese Older Adults: Cross Cultural Comparisons. J Aging Phys Act. 2014;22(1):126-37.

10. Mazo GZ, Petreca DR, Sandreschi PF, Benedetti TR. Valores normativos da aptidão física para idosas brasileiras de 60 a 69 anos de idade. Rev Bras Med Esporte. 2015;21(4):318-22.

11. Rikli RE, Jones CJ. Development and validation of criterion-referenced clinically relevant fitness standards for maintaining physical independence in later years. Gerontologist. 2013;53(2):255-67.

12. Gusi N, Prieto J, Olivares PR, Delgado S, Quesada F, Cebrian C. Normative fitness performance scores of community-dwelling older adults in Spain. J Aging Phys Act. 2012;20(1):106-26.

13. Iniciativa Panamericana sobre la Hipertensión. Reunión de trabajo sobre la medición de la presión arterial: recomendaciones para estudios de población. Rev Panam Salud Publica. 2003;14(5):303-5.
14. Cole TJ, Bellizzi MC, Flegal KM, Dietz WH. Establishing a standard definition for child overweight and obesity worldwide: International survey. BMJ. 2000;320(7244):1240-3.

15. Pan H, Cole TJ. LMSChartmaker. 2006. [acesso em 2015 mar 28]. Disponível em: http://www.healthforallchildren.co.uk

16. Ministry of Education, Department of Physical Education MECSST. (2007). Physical fitness normative scores: cardiopulmonary fitness (index percentage normative scores of cardiopulmonary endurance in 6-65 year-old males and females using the 3-minute step test in the Taiwan Area). [acesso em 2015 abr 20]. Disponivel em: http://www.fitness.org.tw/TW/index.html

17. American College of Sports Medicine; Chodzko-Zajko WJ, Proctor DN, Fiatarone Singh MA, Minson CT, Nigg CR, et al. American College of Sports Medicine position stand. Exercise and physical activity for older adults. Med Sci Sports Exerc. 2009;41(7):1510-30.

18. Woodcock J, Franco OH, Orsini N, Roberts I (2011) Non-vigorous physical activity and all-cause mortality: systematic review and meta-analysis of cohort studies. Int J Epidemiol. 2011;40(1):121-38.

19. Rankin AJ, Rankin AC, MacIntyre P, Hillis WS. Walk or run? Is highintensity exercise more effective than moderate-intensity exercise at reducing cardiovascular risk? Scott Med J. 2012;57(2):99-102.

20. Sui X, Laditka JN, Hardin JW, Blair SN. Estimated functional capacity predicts mortality in older adults. J Am Geriatr Soc. 2007;55(12):1940-7.

21. Vidoni ED, Billinger SA, Lee C, Hamilton J, Burns JM. The physical performance test predicts aerobic capacity sufficient for independence in early-stage Alzheimer disease. J Geriatr Phys Ther. 2012;35(2):72-8

22. Segunda encuesta nacional de calidad de vida en la vejez (2010). Ministerio de desarrollo social. Chile: SENAMA. 2010. [acesso em 2017 ago 1]. Disponível em: www.senama.cl/n3683_10-05-2011.html.

23. Evans T, Van Lerberghe W. The world health report 2008: primary health care-now more than ever. Geneva: World Health Organization; 2008.

24. Cacau LA, de Santana-Filho VJ, Maynard LG, Gomes Neto M, Fernandes M, Carvalho VO. Reference values for the six-minute walk test in healthy children and adolescents: a systematic review. Braz J Cardiovasc Surg. 2016;31(5):381-8. 